\title{
Claudin-1 has tumor suppressive activity and is a direct target of RUNX3 in gastric epithelial cells
}

Ti Ling Chang ${ }^{1}$, Kosei Ito ${ }^{2}$, Tun Kiat Ko ${ }^{1}$, Qiang Liu $^{1}$, Manuel Salto-Tellez ${ }^{1}$, Khay Guan Yeoh $^{3}$, Hiroshi Fukamachi ${ }^{4}$, and Yoshiaki Ito ${ }^{1,5}$

${ }^{1}$ Cancer Science Institute of Singapore, National University of Singapore, Singapore;

${ }^{2}$ Graduate School of Biomedical Sciences, Nagasaki University, Nagasaki, Japan;

${ }^{3}$ Department of Medicine, Faculty of Medicine, National University of Singapore, Singapore; ${ }^{4}$ Department of Molecular Oncology, Tokyo Medical and Dental University, Tokyo, Japan; ${ }^{5}$ Institute of Molecular and Cell Biology, Proteos, Singapore.

K.I. initiated the study, and T.L.C. and K.I. conducted the in vivo and in vitro analyses. T.K.K. conducted the in vitro analyses. Q.L., M.S.-T., and K.G.Y. provided the human clinical materials. H.F. provided mouse tissues and GIF cells. K.I. and T.L.C. wrote the manuscript. K.I and Y.I. supervised the project.

Corresponding authors:

Kosei Ito, $\mathrm{PhD}$

Tel: +81-95-819-7754, Fax: +81095-819-7633, Email: itok@nagasaki-u.ac.jp Yoshiaki Ito, $\mathrm{MD}, \mathrm{PhD}$

Tel: +65-6586-9646, Fax: +65-6779-1117, Email: itoy@imcb.a-star.edu.sg

Abbreviations used in this paper: EMT, epithelial-mesenchymal transition; ZO, zonulaoccluden. 


\begin{abstract}
Background \& Aims: The transcription factor RUNX3 is a gastric tumor suppressor. Tumorigenic Run $\times 3^{-/-}$gastric epithelial cells attach weakly to each other, compared with non-tumorigenic, Runx $3^{+/+}$cells. We aimed to identify RUNX3 target genes that promote cell-cell contact to improve our understanding of RUNX3's role in suppressing gastric carcinogenesis.
\end{abstract}

Methods: We compared gene expression profiles of $R u n x 3^{+/+}$and $R u n x 3^{-/-}$cells and observed down-regulation of genes associated with cell-cell adhesion in Runx $3^{-/}$cells. Reporter, mobility shift, and chromatin immuoprecipitation assays were used to examine the regulation of these genes by RUNX3. Tumorigenesis assays and immunohistological analyses of human gastric tumors were performed to confirm the role of the candidate genes in gastric tumor development.

Results: Mobility shift and ChIP assays revealed that the promoter activity of the gene that encodes the tight junction protein claudin-1 was up-regulated via the binding of RUNX3 to the RUNX consensus sites. The tumorigenicity of gastric epithelial cells from Run $\times 3^{-/}$mice was significantly reduced by restoration of claudin-1 expression, whereas knockdown of claudin-1 increased the tumorigenicity of human gastric cancer cells. Concomitant expression of RUNX3 and claudin-1 was observed in human normal gastric epithelium and cancers.

Conclusions: The tight junction protein claudin-1 has gastric tumor suppressive activity and is a direct transcriptional target of RUNX3. Claudin-1 is downregulated during the epithelial-mesenchymal transition (EMT); RUNX3 might therefore act as a tumor suppressor to antagonize the EMT. 


\section{Introduction}

Gastric cancer remains a major public health problem worldwide. It is the most common epithelial malignancy and is the leading cause of cancer-related death in Asia and in parts of South America. It remains the second most frequently diagnosed malignancy worldwide and is a cause of $12 \%$ of all cancer-related deaths each year ${ }^{1,2}$.

Various genetic and epigenetic alterations of tumor suppressor and tumor-related genes have been associated with the development and progression of gastric cancer. Mutations in $p 53^{3,4}$, -cadherin $^{5}$, and in the transforming growth factor beta (TGF- $\beta$ ) receptor $^{6}$ are involved in gastric carcinogenesis. Oncogenic activation of $\beta$-catenin and $K$ ras and amplification of $c$-erbB2 and c-met have also been reported to be involved in the process $^{7}$. Microsatellite instability (MSI) was observed in 5-10\% of diffuse and $15-40 \%$ of intestinal-type gastric cancer, which is mainly caused by the inactivation of $h M L H 1$, via promoter hypermetylation ${ }^{8}$. Although many genes have been analyzed in attempts to understand the molecular bases of human gastric carcinogenesis, a restricted number of genes that carry frequent alterations have been identified to date.

The Runt-related (RUNX) gene has been documented to play a role in gastrointestinal carcinogenesis. RUNX3 is 1 of the 3 Runt-domain transcription factors that function in the TGF- $\beta$ /SMAD signaling pathway, which is essential for developmental and physiological processes ${ }^{9,10}$. We have shown that loss of RUNX3 abrogates TGF- $\beta$ signaling and that RUNX3 is inactivated in more than $80 \%$ of gastric cancers, not only by gene silencing but also by protein mislocalization ${ }^{11,12}$. RUNX3 directly up-regulates the cyclin-dependent kinase inhibitor, $p 21^{\text {WAF1/Cip113 }}$ and the 
proapoptotic gene, $\mathrm{Bim},{ }^{14,15}$ in response to TGF- $\beta$ signaling and down-regulates $V E G F^{16}$. We thus concluded that $R U N X 3$ is a gastric tumor suppressor gene that controls the growth, apoptosis, and differentiation of gastric epithelial cells ${ }^{17-20}$. Recently, RUNX3 was found to form a ternary complex with $\beta$-catenin/TCF4 and to attenuate the oncogenic Wnt signaling activity in human and mouse intestinal tumors ${ }^{21}$. These results support the contention that RUNX3 functions as a tumor suppressor in gastrointestinal tract carcinogenesis.

In a previous study, we found that mouse embryonic gastric epithelial cells (GIF cells) isolated from E16.5 Runx $3^{-/} p 53^{-/-}$mice are tumorigenic in nude mice, whereas GIF cells from $R u n x 3^{+/+} p 53^{-/-}$mice are not ${ }^{11}$. Furthermore, Runx $3^{-/-}$GIF cells attach weakly to each other and do not form any glandular structures when cultured on collagen gel, while Runx $3^{+/+}$GIF cells formed simple columnar epithelia with occasional glandular structures $^{19}$, which suggests that cell polarity and epithelial sheet formation could not be established in Runx $^{-/-}$gastric epithelial cells.

One of the structures involved in cell-cell adhesion is the tight junction. The proteins that participate in the formation of tight junctions include claudins, occludins, junctional adhesion molecules (JAM), zona occludens (ZO), AF-6 (afadin), and cingulin. Claudins interact directly with occludin, ZO-1, ZO-2, and ZO-3 and indirectly with AF-6 and the myosin-binding molecule cingulin. These protein-protein interactions promote the scaffolding of the tight junction transmembrane proteins, thus providing a link to the actin cytoskeleton for the transduction of regulatory signals to and from tight junctions ${ }^{22,}$ ${ }^{23}$. Because of this ability, tight junction proteins are believed to be involved in the regulation of proliferation, differentiation, and other cellular functions. Claudin- 1 is the 
main component of the tight junction family of proteins and its expression is often celltype- and tissue-dependent ${ }^{24,25}$. Expression of claudin-1 is negatively regulated by 2 related transcription factors, Snail and Slug, which are involved in the induction of epithelial-mesenchymal transition (EMT), which is a normal developmental process characterized by loss of cell adhesion and increased mobility; EMT is now considered to contribute to invasive and metastatic tumor growth ${ }^{26}$.

In this study, we examined the expression of a group of genes related to cell-cell adhesion, to identify RUNX3 target genes that function in cell adhesion and to understand their role in gastric carcinogenesis. We identified claudin-1 as a novel downstream target of RUNX3. The identification of this target gene will contribute to the improvement of our understanding of the mechanism underlying $R U N X 3$-mediated suppression of gastric carcinogenesis. 


\section{Materials and Methods}

\section{Cell lines and cell culture}

The GIF cell lines were isolated from gastric epithelial tissues of 16.5 dpc. $R u n x 3^{-/} p 53^{-}$ /- (GIF-5 and -14) and Runx $3^{+/+} p 53^{-/-}$(GIF-9 and -13) mouse fetuses, as described previously $^{11,19}$. GIF cells were maintained in DMEM supplemented with $10 \%$ fetal bovine serum (FBS).

The SNU16 and SNU719 gastric cancer cell lines were maintained in RPMI-1640 medium supplemented with 10\% FBS. AGS, MKN74, and 293T cells were cultured in DMEM supplemented with 10\% FBS. SNU16 and SNU719 cells were treated with 3 ng/ml of TGF- $\beta$ and $1 \mu \mathrm{g} / \mathrm{ml}$ of TGF- $\beta$ inhibitor (SB431542; GlaxoSmithKline Pharmaceuticals, Brentford Middlesex, United Kingdom) was used for SNU16.

SNU16 cells that expressed antisense DNA against human RUNX3 or FlagRUNX3 stably were generated as described previously ${ }^{12,15}$. SNU719 and MKN74 cells that expressed Flag-tagged human RUNX3 stably were generated via transfection using Lipofectamine 2000 (Invitrogen, Carlsbad, CA) as reported previously ${ }^{15,27}$, followed by selection using $1 \mathrm{mg} / \mathrm{ml} \mathrm{G-418} \mathrm{(Roche} \mathrm{Diagnostics,} \mathrm{Indianapolis,} \mathrm{IN).} \mathrm{SNU16} \mathrm{cells} \mathrm{that}$ expressed antisense DNA against human claudin-1 stably were generated via transfection with the pcDNA3.1 vector (Invitrogen) containing the entire inverted open reading frame (ORF) of the human claudin-1 gene (636 bp), followed by selection using $0.125 \mathrm{mg} / \mathrm{ml}$ Hygromycin (Invitrogen). The endogenous RUNX3 in SNU719 cells was knocked down using shRNA targeting RUNX3 (5'-tcagtagtgggtaccaatctt-3') ${ }^{21}$ and control shRNA targeting GFP (5'-ggctacgtccaggagcgca-3'). GeneClip U1 Hairpin Cloning Systems 
(Promega, Madison, WI) was used as the vector for transfection, and transfectants were selected using $1 \mathrm{mg} / \mathrm{ml} \mathrm{G-418.} \mathrm{GIF-5} \mathrm{and} \mathrm{GIF-14} \mathrm{cells} \mathrm{that} \mathrm{expressed} \mathrm{claudin-1} \mathrm{stably}$ were generated via transfection with the pcDNA3.1 vector containing the entire murine claudin-1 ORF (636 bp) ${ }^{28}$ using Fugene 6 (Roche Diagnostics), followed by selection using $0.125 \mathrm{mg} / \mathrm{ml}$ Hygromycin.

\section{Reverse-transcription polymerase chain reaction and Western blotting}

Total RNA and complementary DNA (cDNA) were obtained using the RNeasy mini kit (QIAGEN, Hilde, Germany) and the Omniscript reverse transcription kit (QIAGEN), respectively. Semiquantitative reverse-transcription polymerase chain reaction (RTPCR) for the detection of claudin-1 and GAPDH was then carried out using the following

PCR primers: 5'-CCAACGCGGGGCTGCAGCT-3' ${ }^{\prime}$ and 5' $^{\prime}$ TTGTTTTCGGGGACAGGA-3' for claudin-1, and 5'GGTCGGAGTCAACGGATTTGGTCG-3' $\quad$ and $\quad 5^{\prime}-$ CCTCCGACGCCTGCTTCACCAC-3' for GAPDH. Quantitative RT-PCR was performed using the real-time TaqMan Fast Universal PCR Master Mix system on an ABI PRISM 7900HT instrument (Applied Biosystems, Foster City, CA) for the detection of RUNX3 (Hs00231709_m1; Applied Biosystems) and human claudin-1 (Hs00221623_m1; Applied Biosystems).

Western blotting was performed using anti-RUNX3 (R3-5G4 ${ }^{12}$; Medical \& Biological Laboratories [MBL], Nagoya, Japan), anti-claudin-1 (18-7362; Zymed, South San Francisco, CA), anti-claudin-2 (51-6100; Zymed), anti-claudin-3 (34-1700; Zymed), anti-claudin-4 (36-4800; Zymed), anti-claudin-7 (34-9100; Zymed), anti-claudin-11 (36- 
4500; Zymed), anti-claudin-16 (34-5400; Zymed), anti-ZO-1 (61-7300; Zymed), antiZO-2 (71-1400; Zymed), anti-ZO-3 (36-4100; Zymed), anti-occludin (71-1500; Zymed), anti-E-cadherin (610181; BD Pharmingen, San Jose, CA), and anti- $\beta$-actin (AC-15; Sigma, St Louis, MO) antibodies.

\section{Reporter assay}

The promoter region of human claudin-1, 1.5kb upstream from the claudin-1 transcription start site, was PCR-amplified from SNU16 genomic DNA using the primers

5'-CGGGGTACCCCCTGGGATACAACACG-3' CGAGCTCCCCAGGCTCGGGAACTGAG-3'. The amplified DNA segment was cloned into the pGL3-Basic vector (E1751; Promega) between the KpnI and SacI restriction sites. Three RUNX binding sites were mutated using the QuickChange XL site-directed mutagenesis kit (Stratagene, La Jolla, CA). AGS cells were transfected with the reporter plasmids and a promoterless pRL-SV40 vector (Promega), in which the SV40 promoter was deleted. The Dual-Luciferase Reporter Assay System (Promega) was used to measure the luciferase activity of the reporter plasmids, which was normalized to the activity of the promoterless pRL-SV40 vector.

\section{Xenografts using nude mice}

GIF-5, GIF-14, and SNU16 cells $\left(5 \times 10^{6}\right.$ cells each) were injected subcutaneously into the flanks and backs of nude mice. Sixty days after injection, tumors were dissected and weighed. 


\section{Immunohistochemistry and immunocytochemistry}

Mouse tissues were fixed with $4 \%$ paraformaldehyde, embedded in paraffin, and sectioned at $5 \mu \mathrm{m}$. Human tissues were fixed with $10 \%$ neutral-buffered formalin, embedded in paraffin, and serially sectioned at $4 \mu \mathrm{m}$. Rehydrated specimens were treated for $40 \mathrm{~min}$ at $96^{\circ} \mathrm{C}$ with an antigen retrieval solution (S1700; DAKO, Glostrup, Denmark). The specimens were incubated with anti-claudin-1 (18-7362; Zymed) or antiRUNX3 (R3-6E9 ${ }^{12}$; MBL) antibodies. The EnVision+ system (K4010; DAKO) was used for visualization of signals.

Cells cultured on glass slides were incubated with rabbit anti-claudin-1 (18-7362; Zymed) antibody. Biotinylated anti-rabbit immunoglobulin G (IgG) (BA-1000; VECTOR Laboratories, Burlingame, CA) and fluorescein-conjugated avidin D (A-2001; VECTOR Laboratories) were subsequently used for immunofluorescence imaging.

\section{Gastric cancer specimens}

Fifty-two gastric adenocarcinoma samples and corresponding non-cancerous tissues were obtained from the Department of Pathology and Surgery of the National University of Singapore, under a protocol approved by the Institutional Review Board.

\section{Electrophoresis mobility shift assay}

Electrophoresis mobility shift assay (EMSA) was performed using the LightShift Chemiluminescent EMSA kit and a Chemiluminescent Nucleic Acid Detection Module (Pierce Biotechnology, Rockford, IL). Nuclear extracts from 293T cells expressing Flagtagged RUNX3 were prepared using NE-PER Nuclear and Cytoplasmic Extraction 
Reagents (Pierce Biotechnology). For supershift of bands, anti-RUNX3 (R3-5G4; MBL) antibody or mouse normal IgG were added after the binding reaction. The following oligonucleotides were used as labeled or unlabeled probes; 5'CTTCCCCTCCCACCACACTCGCACC-3' (wild-type RUNX site [W]) and 5'CTTCCCCTCCCATTACACTCGCACC-3' (mutated RUNX site [M] ) for site $1,5^{\prime}-$ ACACTCGCACCACACACAAAAAGCA-3'

and $5^{\prime}-$ ACACTCGCATTACACACAAAAAGCA-3' (M) for site 2, and $5^{\prime}$ TTCAATGATTCCTAACCACAACAGCACTTCTGACT-3' (W) and 5'TTCAATGATTCCTAATTACAACAGCACTTCTGACT-3' (M) for site 3 . The $5^{\prime}$ end of the site 1 and 3 probes and the 3 ' end of the site 2 probe were biotinylated.

\section{Chromatin immunoprecipitation assay}

Chromatin immunoprecipitation (ChIP) was performed using the chromatin immunoprecipitation assay kit (Upstate) with the anti-RUNX3 antibody (R3-6E9; MBL) or mouse normal IgG (sc-2025; Sigma). The primers used to amplify the DNA fragment were designed to comprise all three RUNX binding sites (sites 1-3): $5^{\prime}-$ AAAACCATAGAAGCTTCCCCTCCC-3' ${ }^{\prime}$ and CCTCTATGTTTCTCCAAAGCTTCC-3'. 


\section{Results}

\section{RUNX3 mediates claudin-1 expression}

Run $3^{-/-}$gastric epithelial cells attached weakly to each other in collagen gel culture in vitro, which suggests the RUNX3 mediates expression of genes responsible for cell-cell contact and for formation of epithelial cell sheets ${ }^{19}$. To identify RUNX3 target genes involved in cell-cell contact, first we compared the gene expression profile of of Runx $^{+/+}$(GIF-9) and Runx $3^{-/-}$(GIF-5) cells. As shown in S.Table 1, we found that the expression of tight junction genes was generally reduced in $R u n x 3^{-/-}$cells. As revealed by Western blot analysis, claudin-1, claudin-3, ZO-3, and occludin were highly expressed in the $R u n \times 3^{+/+}$GIF-9 and -13 cells, whereas no expression or very low levels of these proteins were detected in the Runx $3^{-/-}$GIF-5 and -14 cells (Fig. 1A). Claudin-2, -4, -7, 11 , and -16 were not detected in any of the GIF cell lines, as assessed by Western blotting (data not shown). Inactivation of E-cadherin has been reported in diffuse type gastric cancer $^{5}$; however, its level of expression was similar in all GIF cells, regardless of Runx3 state.

To identify genuine direct targets of RUNX3 among the genes encoding tight junction proteins, we used the human gastric cancer-derived SNU16 cell line, in which we can conditionally activate RUNX3 function. RUNX3 is inactive in the cytoplasm of SNU16 cells; however, it becomes functional when translocated into the nucleus via TGF- $\beta$ treatment ${ }^{12,15}$. Among the tight junction proteins tested, only claudin- 1 was upregulated in a time-dependent manner after addition of TGF- $\beta$ to SNU16 cells (Fig. 1B). This up-regulation was abrogated in the presence of the TGF- $\beta$ inhibitor (Fig. 1C). The 
knockdown of RUNX3 abolished this TGF- $\beta$-mediated up-regulation of claudin-1, at both the protein and the mRNA levels (Fig. 1D). Furthermore, the knockdown of RUNX3 in SNU719 cells which express endogenous RUNX3 at a low level inhibited the TGF- $\beta$ induced claudin-1 expression as well (Fig. 1E). The results show TGF- $\beta$-dependent and RUNX3-mediated induction of claudin-1 in SNU16 and SNU719 cells. On the other hand, overexpression of exogenous RUNX3 up-regulated claudin-1 in SNU719 and a RUNX3negative cell line, MKN74 ${ }^{12,27}$ (Fig. 1F). These results suggest that claudin-1 is a strong RUNX3 target gene candidate and that its expression is positively regulated by RUNX3 in gastric epithelial cells.

Consistent with these results, claudin-1 was clearly immnunodetected at the cellular membrane in $R u n x 3^{+/+}$cells (e.g., GIF-9, -13, and wild-type mouse gastric

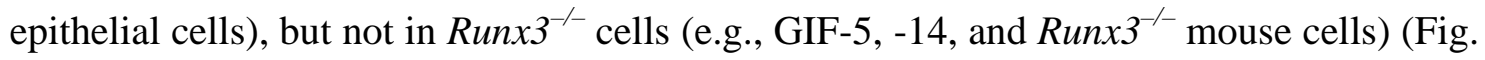
2A, B). Thus, for all follow-up experiments, we focused on the elucidation of the mechanism underlying the RUNX3-mediated regulation of claudin-1 expression.

\section{Claudin-1 is a direct target of RUNX3}

We found that the human claudin-1 promoter region between nucleotides -1176 and 1080 is highly homologous (81\%) to that of the mouse claudin-1 promoter and that it contains three RUNX consensus binding sites (sites 1-3; Fig. 3A). To examine the regulation of human claudin-1 expression by RUNX3 through consensus binding sites, we generated a luciferase reporter construct encompassing $1.5 \mathrm{~kb}$ of sequence upstream from the human claudin-1 transcription start site (Fig. 3B). The three RUNX consensus sites were mutated in turn, as shown in Fig. 3B, and seven types of reporter plasmids, 
termed M1, M2, M3, M1+2, M1+3, M2+3, and M1+2+3, as well as the wild-type (WT) promoter construct, were subjected to reporter assays using the $R U N X 3$-negative cell line AGS. RUNX3 forms complexes with Smads to stimulate transcription of target genes in a cooperative manner after stimulation by TGF- $\beta^{9,13,29}$. We found that the $1.5 \mathrm{~kb}$ human claudin-1 WT promoter was activated by exogenous RUNX3 and was enhanced by coexpression of RUNX3 with Smad3 and Smad4 (Fig. 3C). The activation of the $1.5 \mathrm{~kb}$ human claudin-1 promoter depended on the three RUNX consensus sites, as shown in Fig. 3D.

The direct binding of RUNX3 to the consensus sites in the claudin-1 promoter was confirmed using the EMSA and ChIP assays. As shown in Fig. 3E, RUNX3 specifically bound to the three RUNX consensus sites, as shown by EMSA, and its binding was significantly enhanced by TGF- $\beta$ treatment, as revealed by ChIP assay (Fig. 3F). These results suggest that claudin-1 expression is directly regulated by RUNX3 in gastric epithelial cells.

\section{Restoration of claudin-1 expression suppresses $R u n \times 3^{-/-}$tumorigenicity in nude mice} In a previous study, we showed that GIF cells from $R u n \times 3^{-/} p 53^{-/}$mouse gastric epithelium are tumorigenic in nude mice, whereas those of $\operatorname{Run} x 3^{+/+} p 53^{-/-}$mice are not ${ }^{11}$. As shown in Figs $1 \mathrm{~A}$ and $2 \mathrm{~A}$, the $R u n \times 3^{--}$GIF-5 and -14 cells expressed claudin- 1 at very low or negligible levels. To assess whether claudin-1 acts as a tumor suppressor in gastric epithelial cells, we generated GIF-5 and -14 cells stably expressing exogenous claudin-1 (Fig. 4D) and examined their tumorigenicity by inoculating them into nude mice. The restoration of exogenous claudin-1 expression greatly suppressed the 
tumorigenicity of Runx $3^{-/-}$cells and this tumor suppressive effect was correlated with the level of expression of claudin-1 in these cell lines (Fig. 4A, B, D).

Conversely, we examined the effect of claudin-1 knockdown on the tumorigenesis of human gastric epithelial cells. We transfected SNU16 cells with antisense DNA against human claudin-1 and obtained stable cell lines in which the level of claudin-1 was significantly reduced. The tumorigenicity of these SNU16 cells was inversely correlated with the level of expression of claudin-1 (Fig. 4D). These observations collectively show that claudin-1 has tumor suppressive activity in gastric epithelial cells.

\section{The expression of claudin-1 and RUNX3 is highly correlated in normal human gastric epithelia and human gastric cancers}

The expression patterns of RUNX3 and claudin- 1 in normal gastric epithelium were immunohistochemically examined. Claudin-1 was strongly expressed in surface epithelial cells and chief cells, but was weakly expressed in parietal cells (Fig. 5). RUNX3 was immunodetected in the nucleus of surface epithelial cells and in the nucleus and cytoplasm of chief cells, as reported previously ${ }^{12}$. These results demonstrate that the expression of claudin-1 and RUNX3 is highly correlated in normal human gastric mucosa.

We also examined the expression of these proteins in human gastric cancers. Among the 52 gastric cancer samples tested here, 29 (56\%) were intestinal and 23 (44\%) were diffuse types. Thirty-seven samples (71\%) exhibited RUNX3 inactivation (Table 1). Nucleus RUNX3 expression was scored as positive, whereas no or cytoplasmic RUNX3 expression were scored as negative. Fifteen samples were both RUNX3- and claudin-1positive (29\%; Figure 6A and Table 1), 17 cases were negative for both (33\%; Figure 6B 
and Table 1), and 20 cases were RUNX3-negative but claudin-1-positive (38\%; Table 1). However, no RUNX3-positive and claudin-1-negative cases were found (Table 1). This observation suggests that claudin-1 is a positive target of RUNX3 and that factors other than RUNX3 are also likely to participate in stimulating its expression. SNU16 and SNU719 cells in the absence of TGF- $\beta$ (Fig. 1B-E) and RUNX3-negative MKN74 cells (Fig. 1F) showed the basal level of claudin-1 expression. The mechanism of regulation of claudin-1 expression by the factors other than RUNX3 remains to be studied. Interestingly, however, in the absence of RUNX3 expression, claudin-1 expression appeared less intense when compared with RUNX3-positive cases in all 3 types of gastric cancers analyzed (Fig. 6C).

Taken together, these observations show that claudin- 1 is a positive target of RUNX3 in gastric epithelial cells. 


\section{Discussion}

In the present study, we examined the possible mechanism via which RUNX3, a transcription factor and a potent gastric cancer tumor suppressor, regulates cell-cell adhesion. We found that a major tight junction protein, claudin- 1 , is transcriptionally regulated by RUNX3. Furthermore, exogenous expression of claudin-1 suppressed tumor growth and knockdown of claudin-1 expression enhanced tumor growth. Thus, we concluded that claudin-1 has tumor suppressive activity and is a direct target of RUNX3.

Approximately 75\% of our Runx3 knockout mice died during the first day after birth because of starvation, and none of the mice with the C57BL/6 genetic background survived beyond 10 days ${ }^{11}$. We also observed a characteristic wrinkled skin appearance in our Runx3 knockout mice, similar to that observed in the claudin-1 knockout mice (data not shown). The wrinkled skin appearance, which is a result of the loss of epidermal barrier function, leads to death of the claudin-1 knockout mice within 1 day after birth ${ }^{30}$. Therefore, it is possible that $R u n \times 3^{-/-}$mice also die from the loss of epidermal barrier function in the skin.

RUNX3 has been shown to contribute to tumor suppressor activity as a component of the TGF- $\beta$ tumor suppressor pathway ${ }^{9}$ through the attenuation of cell growth with a CDK inhibitor ${ }^{13}$, induction of apoptosis ${ }^{15}$, and inhibition of angiogenesis ${ }^{16}$ and metastasis ${ }^{31}$ in gastric cancers. Here, we showed that RUNX3 also exerts its tumor suppressor activity by regulating tight junction function in gastric cancer. Thus, RUNX3 may play a central role in the suppression of tumorigenesis, not only by coordinating 
various signaling pathways but also by controlling cell morphology and tissue structures via the regulation of tight junction protein expression.

One of the most exciting developments in the field of cancer research in recent years is the concept of cancer stem cells and their relationship to EMT. The cell-cell contact is usually loosened in cancer cells and epithelial cells acquire mesenchymal cell properties. Snail and Slug are activated by oncogenic stimuli, which in turn repress Ecadherin expression to induce $\mathrm{EMT}^{32}$, 33 . Recently, claudin-1 was also shown to be negatively and positively regulated by Snail/Slug ${ }^{34}$ and p63, respectively, which function primarily in epithelial-mesenchymal development during embryogenesis ${ }^{35}$. This suggests that reduction of claudin-1 expression is a part of the EMT process. As we found that claudin-1 is positively regulated by RUNX3, the tumor suppressor function of RUNX3 may be, at least in part, to inhibit induction of EMT and, perhaps, cancer stem cells.

RUNX3 was found to positively regulate the expression of claudin-1. However, RUNX3 did not alter the expression of E-cadherin. The von Hippel-Lindau (VHL) tumor suppressor gene was shown recently to regulate claudin-1 and occludin, without involving E-cadherin ${ }^{36}$. The similarity between the VHL and RUNX3 tumor suppressor genes in this respect suggests that tight junction proteins are important tumor suppressor targets and loss of tumor suppressors with concomitant loss of tight junction proteins suggests the importance of tight junction proteins and perhaps EMT in carcinogenic processes.

In many types of cancers, TGF- $\beta$ plays a complex dual role. At early stages of epithelial neoplasia the TGF- $\beta$ pathway functions as a tumor suppressor, inhibiting primary tumor growth and inducing apoptosis. At later stages of carcinogenesis, however, 
tumor cells that have developed the ability to bypass these tumor suppressor functions may use TGF- $\beta$ for tumor progression and invasion, promoting $\mathrm{EMT}^{37}$. RUNX3 functions as a tumor suppressor under the TGF- $\beta$-signalling pathway ${ }^{9}$. In this study, we used SNU16 and SNU719 cell lines sensitive to cell growth-inhibitory and apoptosisinducing action of TGF- $\beta^{13,15}$. Using the system for examining the tumor suppressive TGF- $\beta$ function in early stages of epithelial neoplasia, we successfully demonstrated the up-regulation of claudin-1.

Expression of claudin family in gastric and other cancers has been studied by many laboratories but the results are conflicting. Although some investigators observed that claudin-1,-3,-4,-5 and -7 are reduced in diffuse type gastric cancer ${ }^{38-40}$, up-regulation of claudin-7 in intestinal type has also been reported ${ }^{39,40}$. Reports on the expression of claudin family in other types of cancer are also controversial. In breast cancer, decreased expression of claudin-1 and -7 was reported ${ }^{41}$, but increased claudin- 1 and -4 expression in the basal-like subtype ${ }^{42}$ and increased claudin-4 expressin in poor prognosis and high tumor grade ${ }^{43}$ were also published. In colon cancer, while decreased expression of claudin-1 was reported to be associated with higher tumor grade ${ }^{44}$, an opposite conclusion has also been reported ${ }^{45}$. A possible cause of this controversy may be a reflection of the complexity of cancer cells. For example, claudin-7 is shown to be associated with $\mathrm{EpCAM}^{46}$. Association of cellular proteins to claudins in some cases, but not in other cases, might change the antigenicity of claudins. Some investigators reported the expression by semi-quantitative manner, whereas others described simply in a positive or negative fashion. To avoid conflicting results, precise mechanisms of 
regulation of each claudin expression and their subcellular localizarion would have to be studied.

In the present study, we found that claudin-1 is a direct target of RUNX3. The latter is deeply involved in the TGF- $\beta$-signaling pathway, which is well related to gastric carcinogenesis. The stage of carcinogenesis at which the expression of claudin- 1 is downregulated and how this correlates with other signaling cascades (e.g., oncogenic Wnt signaling) remain to be determined. 


\section{Acknowledgments}

We thank Dr Eveline Schneeberger for providing the murine claudin-1 cDNA and Tomoko Ito and Kotaro Tada for technical assistance.

\section{Conflicts of interest}

The authors disclose no conflicts.

\section{Funding}

Supported by the Agency for Science, Technology, and Research, Singapore, by the Singapore Millenium Foundation scholarship (to T.L.C.), and by the Special Coordination Funds for Promoting Science and Technology of the Ministry of Education, Culture, Sports, Science, and Technology, Japan (to K.I.). 


\section{References}

1. Parkin DM, Pisani P, Ferlay J. Global cancer statistics. CA Cancer J Clin 1999;49:33-64, 1.

2. Zheng L, Wang L, Ajani J, Xie K. Molecular basis of gastric cancer development and progression. Gastric Cancer 2004;7:61-77.

3. Tamura G, Kihana T, Nomura K, Terada M, Sugimura T, Hirohashi S. Detection of frequent p53 gene mutations in primary gastric cancer by cell sorting and polymerase chain reaction single-strand conformation polymorphism analysis. Cancer Res 1991;51:3056-8.

4. $\quad$ Kim IJ, Kang HC, Shin Y, Park HW, Jang SG, Han SY, Lim SK, Lee MR, Chang HJ, Ku JL, Yang HK, Park JG. A TP53-truncating germline mutation (E287X) in a family with characteristics of both hereditary diffuse gastric cancer and LiFraumeni syndrome. J Hum Genet 2004;49:591-5.

5. Guilford P, Hopkins J, Harraway J, McLeod M, McLeod N, Harawira P, Taite H, Scoular R, Miller A, Reeve AE. E-cadherin germline mutations in familial gastric cancer. Nature 1998;392:402-5.

6. Park K, Kim SJ, Bang YJ, Park JG, Kim NK, Roberts AB, Sporn MB. Genetic changes in the transforming growth factor beta (TGF-beta) type II receptor gene in human gastric cancer cells: correlation with sensitivity to growth inhibition by TGF-beta. Proc Natl Acad Sci U S A 1994;91:8772-6.

7. Ushijima T, Sasako M. Focus on gastric cancer. Cancer Cell 2004;5:121-5.

8. $\quad$ Fang DC, Wang RQ, Yang SM, Yang JM, Liu HF, Peng GY, Xiao TL, Luo YH. Mutation and methylation of hMLH1 in gastric carcinomas with microsatellite instability. World J Gastroenterol 2003;9:655-9.

9. Ito Y, Miyazono K. RUNX transcription factors as key targets of TGF-beta superfamily signaling. Curr Opin Genet Dev 2003;13:43-7.

10. Ito Y. RUNX genes in development and cancer: regulation of viral gene expression and the discovery of RUNX family genes. Adv Cancer Res 2008;99:33-76.

11. Li QL, Ito K, Sakakura C, Fukamachi H, Inoue K, Chi XZ, Lee KY, Nomura S, Lee CW, Han SB, Kim HM, Kim WJ, Yamamoto H, Yamashita N, Yano T, Ikeda T, Itohara S, Inazawa J, Abe T, Hagiwara A, Yamagishi H, Ooe A, Kaneda A, Sugimura T, Ushijima T, Bae SC, Ito Y. Causal relationship between the loss of RUNX3 expression and gastric cancer. Cell 2002;109:113-24.

12. Ito K, Liu Q, Salto-Tellez M, Yano T, Tada K, Ida H, Huang C, Shah N, Inoue M, Rajnakova A, Hiong KC, Peh BK, Han HC, Ito T, Teh M, Yeoh KG, Ito Y. RUNX3, a novel tumor suppressor, is frequently inactivated in gastric cancer by protein mislocalization. Cancer Res 2005;65:7743-50.

13. Chi XZ, Yang JO, Lee KY, Ito K, Sakakura C, Li QL, Kim HR, Cha EJ, Lee YH, Kaneda A, Ushijima T, Kim WJ, Ito Y, Bae SC. RUNX3 suppresses gastric epithelial cell growth by inducing p21(WAF1/Cip1) expression in cooperation with transforming growth factor \{beta\}-activated SMAD. Mol Cell Biol 2005;25:8097-107. 
14. Yamamura Y, Lee WL, Inoue K, Ida H, Ito Y. RUNX3 cooperates with FoxO3a to induce apoptosis in gastric cancer cells. J Biol Chem 2006;281:5267-76.

15. Yano T, Ito K, Fukamachi H, Chi XZ, Wee HJ, Inoue K, Ida H, Bouillet P, Strasser A, Bae SC, Ito Y. The RUNX3 tumor suppressor upregulates Bim in gastric epithelial cells undergoing transforming growth factor beta-induced apoptosis. Mol Cell Biol 2006;26:4474-88.

16. Peng Z, Wei D, Wang L, Tang H, Zhang J, Le X, Jia Z, Li Q, Xie K. RUNX3 inhibits the expression of vascular endothelial growth factor and reduces the angiogenesis, growth, and metastasis of human gastric cancer. Clin Cancer Res 2006;12:6386-94.

17. Fukamachi H. Runx3 controls growth and differentiation of gastric epithelial cells in mammals. Dev Growth Differ 2006;48:1-13.

18. Fukamachi H, Ito K. Growth regulation of gastric epithelial cells by Runx3. Oncogene 2004;23:4330-5.

19. Fukamachi H, Ito K, Ito Y. Runx3-/- gastric epithelial cells differentiate into intestinal type cells. Biochem Biophys Res Commun 2004;321:58-64.

20. Ito K, Inoue KI, Bae SC, Ito Y. Runx3 expression in gastrointestinal tract epithelium: resolving the controversy. Oncogene 2009;28:1379-84.

21. Ito K, Lim AC, Salto-Tellez M, Motoda L, Osato M, Chuang LS, Lee CW, Voon DC, Koo JK, Wang H, Fukamachi H, Ito Y. RUNX3 attenuates beta-catenin/T cell factors in intestinal tumorigenesis. Cancer Cell 2008;14:226-37.

22. Furuse M, Tsukita S. Claudins in occluding junctions of humans and flies. Trends Cell Biol 2006;16:181-8.

23. Cordenonsi M, D'Atri F, Hammar E, Parry DA, Kendrick-Jones J, Shore D, Citi S. Cingulin contains globular and coiled-coil domains and interacts with ZO-1, ZO-2, ZO-3, and myosin. J Cell Biol 1999;147:1569-82.

24. Tepass U. Claudin complexities at the apical junctional complex. Nat Cell Biol 2003;5:595-7.

25. Tsukita S, Yamazaki Y, Katsuno T, Tamura A. Tight junction-based epithelial microenvironment and cell proliferation. Oncogene 2008;27:6930-8.

26. Mani SA, Guo W, Liao MJ, Eaton EN, Ayyanan A, Zhou AY, Brooks M, Reinhard F, Zhang CC, Shipitsin M, Campbell LL, Polyak K, Brisken C, Yang J, Weinberg RA. The epithelial-mesenchymal transition generates cells with properties of stem cells. Cell 2008;133:704-15.

27. Guo WH, Weng LQ, Ito K, Chen LF, Nakanishi H, Tatematsu M, Ito Y. Inhibition of growth of mouse gastric cancer cells by Runx3, a novel tumor suppressor. Oncogene 2002;21:8351-5.

28. McCarthy KM, Francis SA, McCormack JM, Lai J, Rogers RA, Skare IB, Lynch $\mathrm{RD}$, Schneeberger EE. Inducible expression of claudin-1-myc but not occludinVSV-G results in aberrant tight junction strand formation in MDCK cells. J Cell Sci 2000;113 Pt 19:3387-98.

29. Hanai J, Chen LF, Kanno T, Ohtani-Fujita N, Kim WY, Guo WH, Imamura T, Ishidou Y, Fukuchi M, Shi MJ, Stavnezer J, Kawabata M, Miyazono K, Ito Y. Interaction and functional cooperation of PEBP2/CBF with Smads. Synergistic induction of the immunoglobulin germline Calpha promoter. J Biol Chem 1999;274:31577-82. 
30. Furuse M, Hata M, Furuse K, Yoshida Y, Haratake A, Sugitani Y, Noda T, Kubo A, Tsukita S. Claudin-based tight junctions are crucial for the mammalian epidermal barrier: a lesson from claudin-1-deficient mice. J Cell Biol 2002;156:1099-111.

31. Sakakura C, Hasegawa K, Miyagawa K, Nakashima S, Yoshikawa T, Kin S, Nakase Y, Yazumi S, Yamagishi H, Okanoue T, Chiba T, Hagiwara A. Possible involvement of RUNX3 silencing in the peritoneal metastases of gastric cancers. Clin Cancer Res 2005;11:6479-88.

32. Batlle E, Sancho E, Franci C, Dominguez D, Monfar M, Baulida J, Garcia De Herreros A. The transcription factor snail is a repressor of E-cadherin gene expression in epithelial tumour cells. Nat Cell Biol 2000;2:84-9.

33. Cano A, Perez-Moreno MA, Rodrigo I, Locascio A, Blanco MJ, del Barrio MG, Portillo F, Nieto MA. The transcription factor snail controls epithelialmesenchymal transitions by repressing E-cadherin expression. Nat Cell Biol 2000;2:76-83.

34. Martinez-Estrada OM, Culleres A, Soriano FX, Peinado H, Bolos V, Martinez FO, Reina M, Cano A, Fabre M, Vilaro S. The transcription factors Slug and Snail act as repressors of Claudin-1 expression in epithelial cells. Biochem J 2006;394:44957.

35. Lopardo T, Lo Iacono N, Marinari B, Giustizieri ML, Cyr DG, Merlo G, Crosti F, Costanzo A, Guerrini L. Claudin-1 is a p63 target gene with a crucial role in epithelial development. PLoS ONE 2008;3:e2715.

36. Harten SK, Shukla D, Barod R, Hergovich A, Balda MS, Matter K, Esteban MA, Maxwell PH. Regulation of renal epithelial tight junctions by the von HippelLindau tumor suppressor gene involves occludin and claudin 1 and is independent of E-cadherin. Mol Biol Cell 2009;20:1089-101.

37. Massague J. TGFbeta in Cancer. Cell 2008;134:215-30.

38. Soini Y, Tommola S, Helin H, Martikainen P. Claudins 1, 3, 4 and 5 in gastric carcinoma, loss of claudin expression associates with the diffuse subtype. Virchows Arch 2006;448:52-8.

39. Johnson AH, Frierson HF, Zaika A, Powell SM, Roche J, Crowe S, Moskaluk CA, El-Rifai W. Expression of tight-junction protein claudin-7 is an early event in gastric tumorigenesis. Am J Pathol 2005;167:577-84.

40. Park JY, Park KH, Oh TY, Hong SP, Jeon TJ, Kim CH, Park SW, Chung JB, Song SY, Bang S. Up-regulated claudin 7 expression in intestinal-type gastric carcinoma. Oncol Rep 2007;18:377-82.

41. Hoevel T, Macek R, Swisshelm K, Kubbies M. Reexpression of the TJ protein CLDN1 induces apoptosis in breast tumor spheroids. Int J Cancer 2004;108:37483.

42. Blanchard AA, Skliris GP, Watson PH, Murphy LC, Penner C, Tomes L, Young TL, Leygue E, Myal Y. Claudins 1, 3, and 4 protein expression in ER negative breast cancer correlates with markers of the basal phenotype. Virchows Arch 2009;454:647-56.

43. Lanigan F, McKiernan E, Brennan DJ, Hegarty S, Millikan RC, McBryan J, Jirstrom K, Landberg G, Martin F, Duffy MJ, Gallagher WM. Increased claudin-4 
expression is associated with poor prognosis and high tumour grade in breast cancer. Int J Cancer 2009;124:2088-97.

44. Resnick MB, Konkin T, Routhier J, Sabo E, Pricolo VE. Claudin-1 is a strong prognostic indicator in stage II colonic cancer: a tissue microarray study. Mod Pathol 2005;18:511-8.

45. Dhawan P, Singh AB, Deane NG, No Y, Shiou SR, Schmidt C, Neff J, Washington MK, Beauchamp RD. Claudin-1 regulates cellular transformation and metastatic behavior in colon cancer. J Clin Invest 2005;115:1765-76.

46. Nubel T, Preobraschenski J, Tuncay H, Weiss T, Kuhn S, Ladwein M, Langbein L, Zoller M. Claudin-7 regulates EpCAM-mediated functions in tumor progression. Mol Cancer Res 2009;7:285-99. 


\section{Figure Legends}

Figure 1. RUNX3 mediates the TGF- $\beta$-induced expression of claudin-1.

(A) Expression of the indicated tight junction proteins and E-cadherin in the Runx $3^{-/}$ GIF-5 and -14 cells and in the Runx $3^{+/+}$GIF-9 and -13 cells, as revealed by Western blot analysis.

(B) Induction of the expression of the indicated tight junction proteins and E-cadherin by TGF- $\beta$ in SNU16 cells, as revealed by Western blot analysis.

(C) Abolishment of the TGF- $\beta$-induced claudin- 1 expression by the TGF- $\beta$ inhibitor in SNU16 cells, as revealed by Western blot analysis.

(D) The TGF- $\beta$-induced claudin-1 expression was inhibited by RUNX3 knockdown in SNU16 cells, as revealed by RT-PCR and Western blot analyses. RUNX3 was knocked down using an antisense DNA against RUNX3 (AS-SNU16).

(E) The TGF- $\beta$-induced claudin-1 expression was inhibited by RUNX3 knockdown in SNU719 cells, as revealed by Western blot analyses. RUNX3 was knocked down using a shRNA targeting RUNX3 (sh-RUNX3). A shRNA targeting GFP (sh-GFP) was used as a control.

(F) Up-regulation of claudin-1 by exogenous Flag-tagged RUNX3 (Flag-RUNX3) in SNU719 and MKN74 cells, as revealed by Western blot analyses. The exogenous FlagRUNX3 (exo) and endogenous RUNX3 (endo) were detected using an anti-RUNX3 antibody (R3-5G4) in SNU719 cells. Cells were transfected with the pcDNA3 as a control (Vector). 


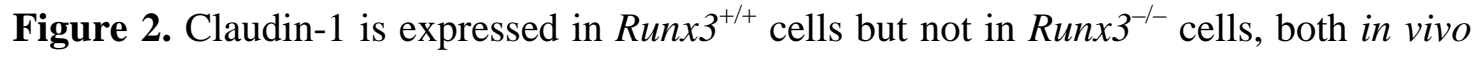
and in vitro.

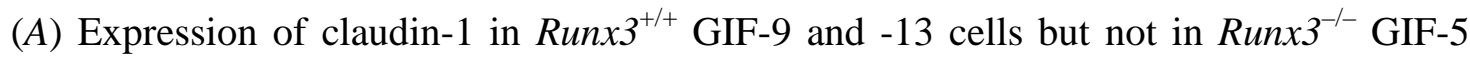
and -14 cells in vitro, as assessed by immunocytochemical analysis.

(B) Expression of claudin-1 in wild-type (WT) but not in Runx $3^{--}(-/-)$samples from the stomach of neonatal mice in vivo, as revealed by immunocytochemical analysis. Specimens were counterstained with hematoxylin. Scale bars, $100 \mu \mathrm{m}$.

Figure 3. RUNX3 regulates claudin-1 expression through the RUNX consensus sites present in its promoter.

(A) Three RUNX consensus sites (sites 1-3) are located in the highly conserved claudin1 promoter region. The figure shows nucleotides -1176 to -1080 of the human claudin- 1 promoter.

(B) Mutations (M1 to M3) were introduced in the RUNX consensus sites, upstream from the human claudin-1 transcriptional start site.

(C) The Claudin-1 promoter was activated by RUNX3 and was enhanced by coexpression of RUNX3 with Smad3 and Smad4 in AGS cells. The luciferase activity was normalized to the activity of the promoterless pRL-SV40 vector, which was used as an internal control.

(D) Activity of the WT and of the seven mutant reporter constructs (M1, M2, M3, M1+2, $\mathrm{M} 1+3$, M2+3, and $\mathrm{M} 1+2+3$ ) shown in panel $\mathrm{B}$ in AGS cells. AGS cells were cotransfected with the control vector or with expression vectors for RUNX3 and/or 
Smad3 and Smad4. The luciferase activity was normalized to the activity of the promoterless pRL-SV40 vector, which was used as an internal control.

(E) Direct binding of RUNX3 to the three RUNX consensus sites (sites 1-3; see panel A) in the promoter, as revealed by EMSA. The nuclear extracts of 293T cells expressing exogenous RUNX3 $(+)$ or the empty control vector $(-)$ were incubated with the wild-type (W) and RUNX site-mutated (M) probes. To shift the RUNX3/probe complexes, an antiRUNX3 antibody (R3-5G4; $\alpha$ R3) and a normal mouse IgG (IgG) were added. The RUNX3/probe complexes (arrow), bands shifted by the anti-RUNX3 antibody (SS), and non-specific bands (asterisk) were detected.

(F) Direct binding of RUNX3 to the RUNX consensus sites in the promoter, as revealed by ChIP analysis. TGF- $\beta$-treated SNU16 cells were subjected to ChIP analysis using an anti-RUNX3 antibody or a normal murine IgG. DNA precipitates were PCR-amplified (30, 32, or 35 cycles) using primers for the human claudin-1 promoter region (which contains three RUNX consensus sites) or for GAPDH, which was used as an internal control.

Figure 4. Tumor suppressive effect of claudin-1 in gastric epithelial cells.

( $A$ and $B$ ) Weight of tumors formed by Runx $3^{-/-}$GIF-5 (A) and -14 (B) cells transfected with plasmids expressing mouse claudin-1 (clones 1 and 2; Cl-1 and -2). GIF-5 and -14 cells expressing the empty vector (pcDNA3) were used as controls.

(C) Weight of tumors formed by SNU16 cells. SNU16 cells stably expressing an antisense DNA against human claudin-1 (clones 1 and 2; AS-Cl-1 and -2) and control SNU16 cells expressing the empty vector (pcDNA3) were inoculated into nude mice. 
(D) Expression of exogenous mouse claudin-1 in GIF-5 and -14 cells and of endogenous human claudin-1 in SNU16 cells, as revealed by Western blot analysis.

Figure 5. Expression of RUNX3 and claudin-1 in normal human gastric epithelium. Boxed regions are enlarged below. Specimens were counterstained with hematoxylin. Scale bars, $100 \mu \mathrm{m}$.

Figure 6. Expression of RUNX3 and claudin-1 in human gastric cancer samples.

(A) Claudin-1-positive and RUNX3-positive gastric cancer samples. Intestinal and diffuse types are shown. Membranous claudin-1 and nuclear RUNX3 were detected.

(B) Claudin-1-negative and RUNX3-negative gastric cancer samples. Intestinal and diffuse types are shown. RUNX3 was retained in the cytoplasm in intestinal gastric cancer samples.

(C) The level of expression of claudin-1 was lower in RUNX3-negative samples than in RUNX3-positive samples. (i), (iv) and (vi) showed membranous staining of claudin-1. (ii), (iii) \& (v) showed membranous and cytoplasmic staining of claudin-1. Specimens were counterstained with hematoxylin. Scale bars, $100 \mu \mathrm{m}$. 
Table 1. Expression of RUNX3 and claudin-1 in intestinal and diffuse types of gastric cancer

$\begin{array}{lllll} & \text { RUNX3- } & \text { RUNX3- } & \text { RUNX3- } & \text { RUNX3- } \\ & \text { negative/ } & \text { positive/ } & \text { negative/ } & \text { positive/ } \\ & \text { claudin-1- } & \text { claudin-1- } & \text { claudin-1- } & \text { claudin-1- } \\ & \text { negative } & \text { negative } & \text { positive } & \text { positive } \\ & \text { n (\%) } & \text { n (\%) } & \text { n (\%) } & n(\%) \\ \text { Intestinal } & 9(31 \%) & 0(0 \%) & 15(52 \%) & 5(17 \%) \\ (n=29) & 8(35 \%) & 0(0 \%) & 5(22 \%) & 10(43 \%) \\ \text { Diffuse } & & & & \\ (n=23) & 17(33 \%) & 0(0 \%) & 20(38 \%) & 15(29 \%) \\ \text { Total } & & & & \end{array}$

RUNX3-negative cases contain the cases showing cytoplasmic localization of RUNX3. 
Figure 1.

A

B

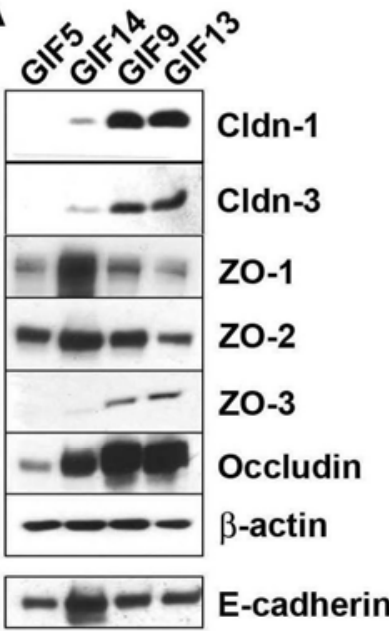

C

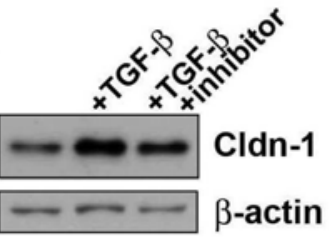

E
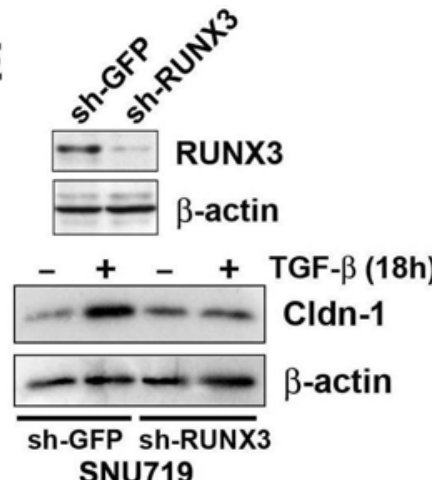

D +TGF $-\beta \quad$ +TGF $-\beta$
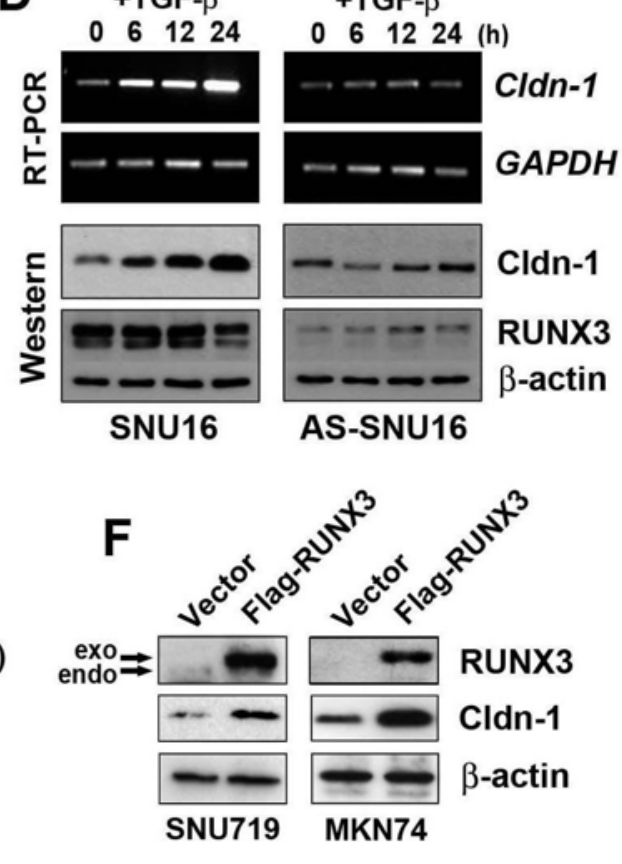
Figure 2.

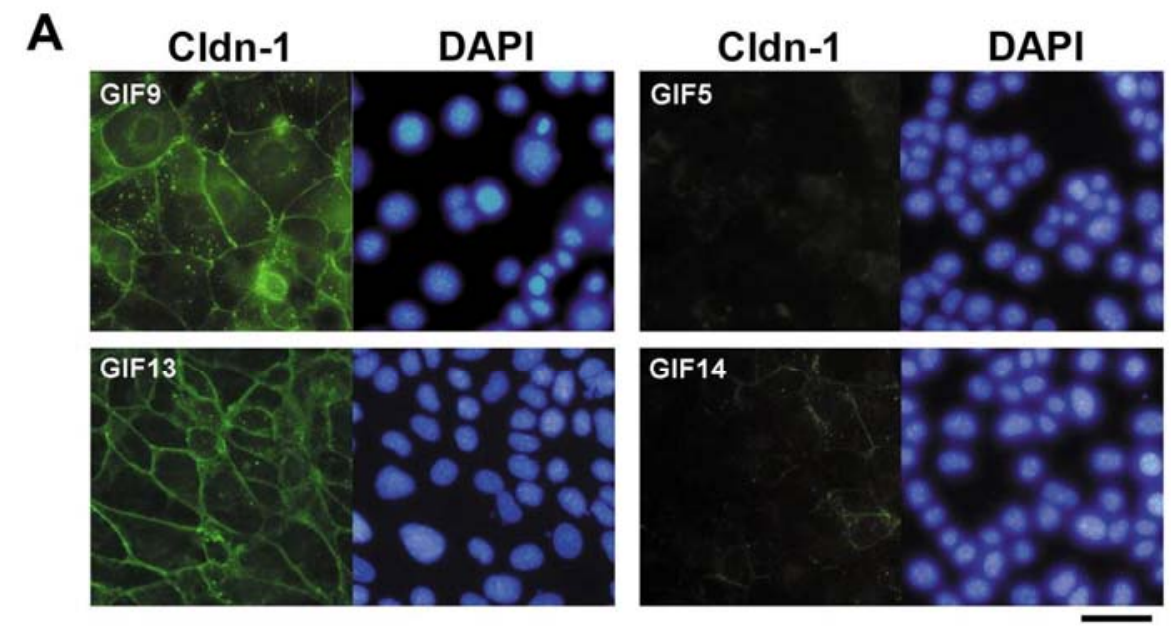

B
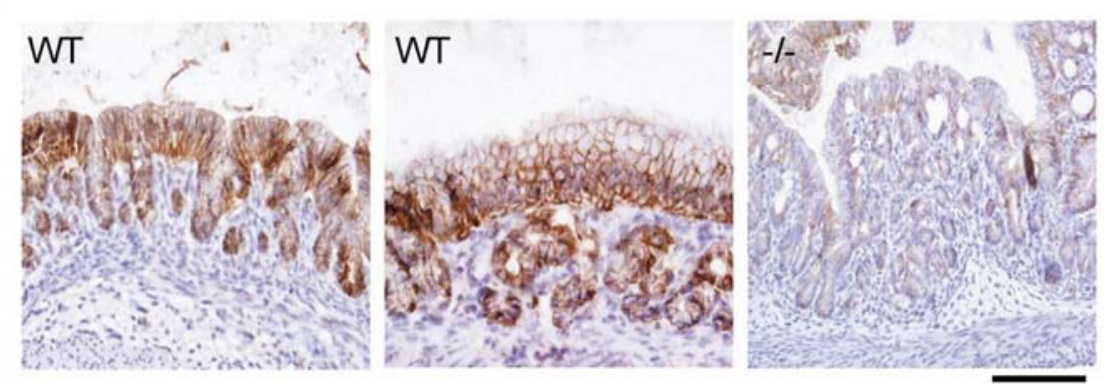
Figure 3.

A

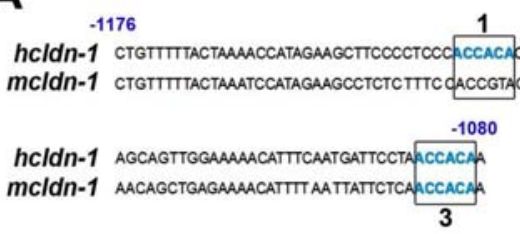

C

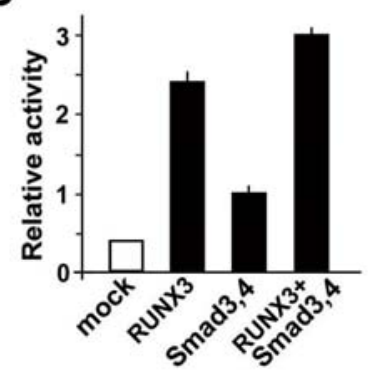

D

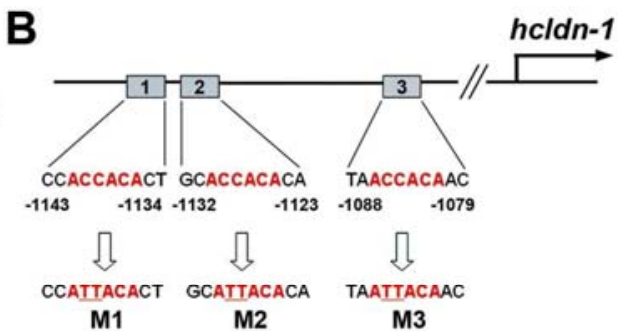

E

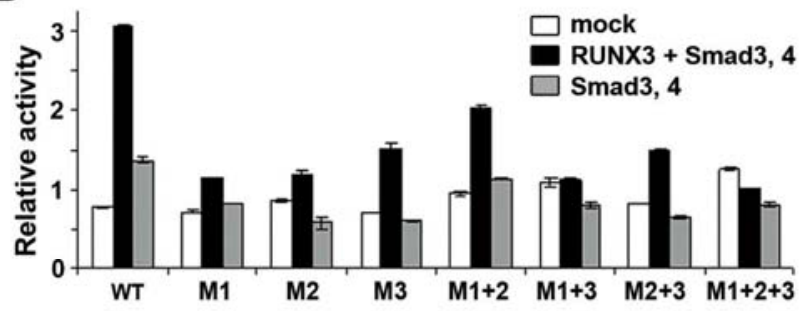

$+\lg G+a R 3$

RUNX3: $\dot{\mathrm{w}}+\stackrel{+}{\mathrm{W}}+\stackrel{+}{\mathrm{W}}+\stackrel{+}{\mathrm{W}}+\stackrel{+}{\mathrm{M}}+\stackrel{+}{\mathrm{W}} \underset{\mathrm{W}}{ }$

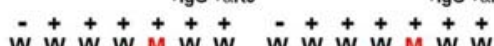

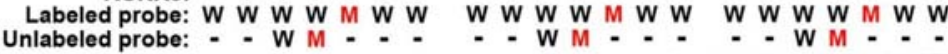
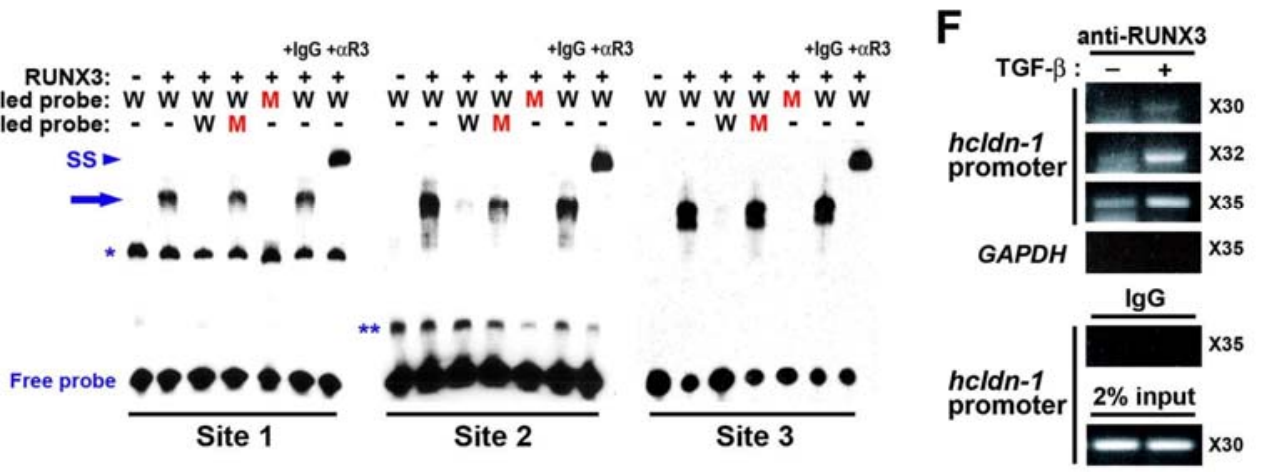
Figure 4.

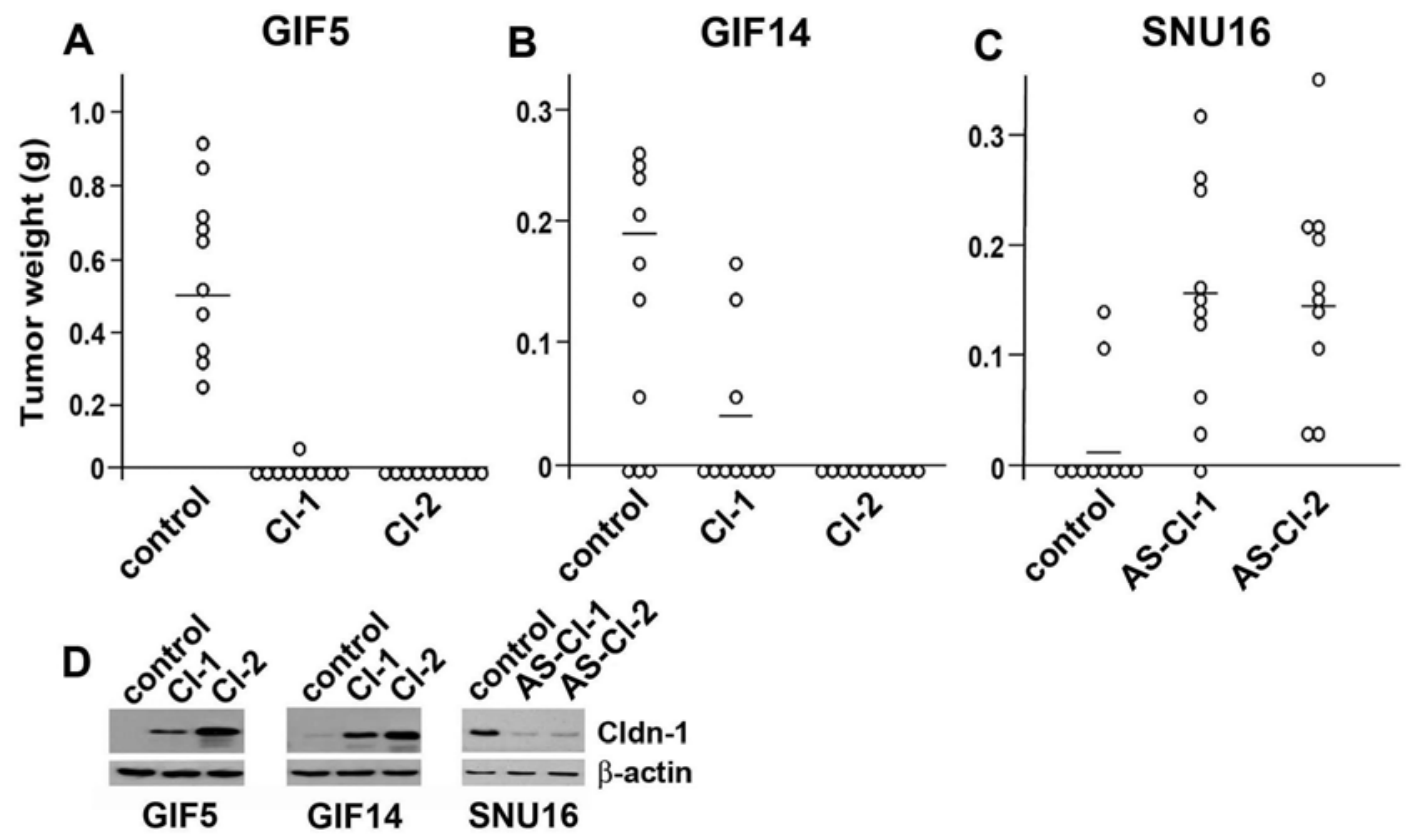


Figure 5.

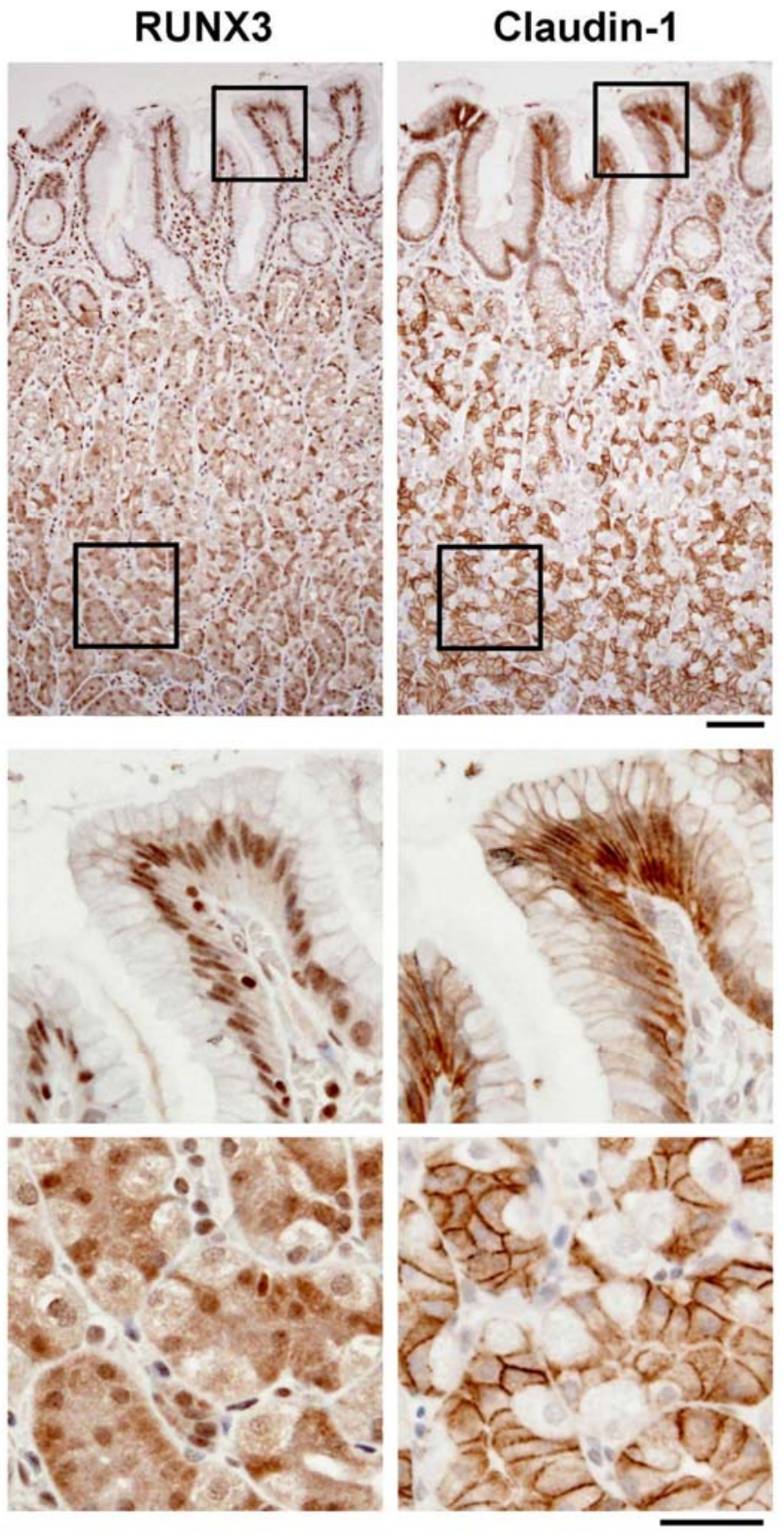


Figure 6.
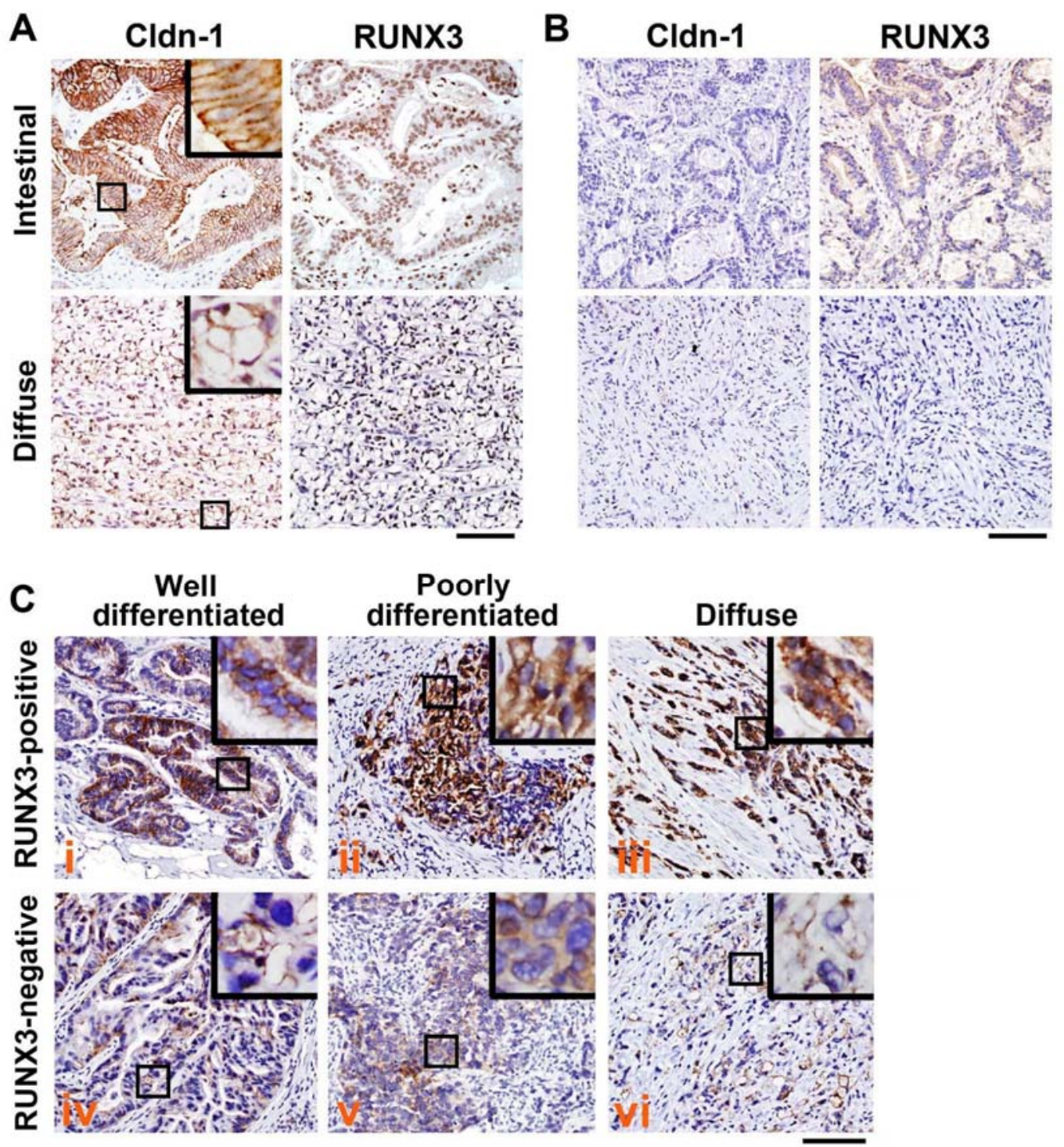
Supplementary Table 1. Expression Profile of Genes Associated With Cell-Cell Adhesion in Runx $3^{-1-}$ GIF-5 vs Runx $3^{+/+}$GIF-9 Cells, as Assessed by Oligonucleotide Microarray Analysis

\begin{tabular}{|c|c|c|c|}
\hline $\begin{array}{l}\text { Entrez gene } \\
\text { ID }\end{array}$ & $\begin{array}{l}\text { Gene } \\
\text { symbol }\end{array}$ & Gene name & $\begin{array}{l}\text { Ratio } \\
\text { (GIF-5/GIF-9) }\end{array}$ \\
\hline 2802 & Cldn1 & Claudin-1 & 0.02 \\
\hline 3188 & Cldn1 & Claudin-1 & 0.03 \\
\hline 23812 & Cldn3 & Claudin-3 & 0.05 \\
\hline 21894 & Cldn 4 & Claudin-4 & 0.02 \\
\hline 30129 & Cldn6 & Claudin-6 & 0.46 \\
\hline 35973 & Cldn7 & Claudin-7 & 0.04 \\
\hline 25782 & Cldn9 & Claudin-9 & 0.63 \\
\hline 17740 & Cldn12 & Claudin-12 & 1.57 \\
\hline 31760 & Cldn14 & Claudin-14 & 1.09 \\
\hline 34226 & Cldn15 & Claudin-15 & 2.07 \\
\hline 4033 & Cldn18 & Claudin-18 & 1.13 \\
\hline 13904 & Cldnd1 & Claudin domain containing 1 & 1.05 \\
\hline 28033 & Cldnd1 & Claudin domain containing 1 & 1.06 \\
\hline 42954 & Ocln & Occludin & 0.53 \\
\hline 43157 & Ocln & Occludin & 0.58 \\
\hline
\end{tabular}




\begin{tabular}{|c|c|c|c|}
\hline 487 & Jup & Junction plakoglobin & 0.5 \\
\hline 39262 & Zfp120 & Zinc finger protein 120 & 0.75 \\
\hline 23540 & Sympk & Symplekin & 1.01 \\
\hline 17415 & Calr3 & Calreticulin 3 & 4.3 \\
\hline 8846 & Calr & Calreticulin & 0.51 \\
\hline 8947 & Calr & Calreticulin & 0.65 \\
\hline 13784 & Cdk4 & Cyclin-dependent kinase 4 & 0.85 \\
\hline 24747 & Cdk6 & Cyclin-dependent kinase 6 & 1.58 \\
\hline 25100 & Cdk6 & Cyclin-dependent kinase 6 & 1.51 \\
\hline 25691 & Cdk6 & Cyclin-dependent kinase 6 & 2.14 \\
\hline 3179 & Jub & Ajuba & 1.75 \\
\hline 6774 & Zyx & Zyxin & 1.12 \\
\hline 25825 & Pxn & Paxillin & 0.56 \\
\hline 34015 & Pxn & Paxillin & 0.81 \\
\hline 14888 & Fhl2 & Four and a half LIM domains 2 & 1.12 \\
\hline 16769 & Trip6 & Thyroid hormone receptor interactor 6 & 0.92 \\
\hline 4621 & Trip6 & Thyroid hormone receptor interactor 6 & 0.89 \\
\hline 42961 & Ashl1 & $\begin{array}{l}\text { Ash1 (absent, small, or homeotic) like } \\
\text { (Drosophila) }\end{array}$ & 0.7 \\
\hline
\end{tabular}




\begin{tabular}{|c|c|c|c|}
\hline 218 & Ashl1 & $\begin{array}{l}\text { Ash1 (absent, small, or homeotic) like } \\
\text { (Drosophila) }\end{array}$ & 0.6 \\
\hline 12639 & Ctnna1 & Catenin (cadherin-associated protein), $\alpha 1$ & 0.85 \\
\hline 9543 & Ctnnal1 & $\begin{array}{l}\text { Catenin (cadherin-associated protein), } \alpha \text {-like } \\
1\end{array}$ & 0.44 \\
\hline 29898 & Ctnnal1 & $\begin{array}{l}\text { Catenin (cadherin-associated protein), } \alpha \text {-like } \\
1\end{array}$ & 0.56 \\
\hline 32399 & Ctnnal1 & $\begin{array}{l}\text { Catenin (cadherin-associated protein), } \alpha \text {-like } \\
1\end{array}$ & 0.92 \\
\hline 34600 & Ctnnal1 & $\begin{array}{l}\text { Catenin (cadherin-associated protein), } \alpha \text {-like } \\
1\end{array}$ & 0.52 \\
\hline 6845 & Ctnnb1 & Catenin (cadherin-associated protein), $\beta 1$ & 1.16 \\
\hline 7115 & Ctnnb1 & Catenin (cadherin-associated protein), $\beta 1$ & 1.47 \\
\hline 5128 & Ctnnb1 & Catenin (cadherin-associated protein), $\beta 1$ & 1.11 \\
\hline 13598 & Ctnnb1 & Catenin (cadherin-associated protein), $\beta 1$ & 1.12 \\
\hline 26926 & Ctnnb1 & Catenin (cadherin-associated protein), $\beta 1$ & 1.13 \\
\hline 30387 & Ctnnb1 & Catenin (cadherin-associated protein), $\beta 1$ & 1.12 \\
\hline 31524 & Ctnnb1 & Catenin (cadherin-associated protein), $\beta 1$ & 1.13 \\
\hline 33613 & Ctnnb1 & Catenin (cadherin-associated protein), $\beta 1$ & 1.13 \\
\hline 33796 & Ctnnb1 & Catenin (cadherin-associated protein), $\beta 1$ & 1.11 \\
\hline
\end{tabular}




\begin{tabular}{|c|c|c|c|}
\hline 35059 & Ctnnb1 & Catenin (cadherin-associated protein), $\beta 1$ & 1.29 \\
\hline 35625 & Ctnnb1 & Catenin (cadherin-associated protein), $\beta 1$ & 1.17 \\
\hline 36727 & Ctnnb1 & Catenin (cadherin-associated protein), $\beta 1$ & 1.12 \\
\hline 34740 & Ctnnbl1 & $\begin{array}{l}\text { Catenin (cadherin-associated protein), } \beta \text {-like } \\
1\end{array}$ & 1.05 \\
\hline 35364 & Ctnnbl1 & $\begin{array}{l}\text { Catenin (cadherin-associated protein), } \beta \text {-like } \\
1\end{array}$ & 1.06 \\
\hline 6957 & Ctnnd1 & Catenin (cadherin-associated protein), $\delta 1$ & 1.06 \\
\hline 7756 & Ctnnd1 & Catenin (cadherin-associated protein), $\delta 1$ & 1.51 \\
\hline 38639 & Ctnnd1 & Catenin (cadherin-associated protein), $\delta 1$ & 1.94 \\
\hline 7368 & Ctnnbip1 & Catenin $\beta$ interacting protein 1 & 0.91 \\
\hline 188 & Cdh1 & Cadherin 1 & 0.78 \\
\hline 4370 & Cdh1 & Cadherin 1 & 0.78 \\
\hline 14130 & Cdh1 & Cadherin 1 & 0.82 \\
\hline 20989 & Cdh1 & Cadherin 1 & 0.81 \\
\hline 24570 & Cdh1 & Cadherin 1 & 0.81 \\
\hline 28517 & Cdh1 & Cadherin 1 & 0.8 \\
\hline 29329 & Cdh1 & Cadherin 1 & 0.8 \\
\hline 33419 & Cdh1 & Cadherin 1 & 0.8 \\
\hline
\end{tabular}




\begin{tabular}{|c|c|c|c|}
\hline 36281 & Cdh1 & Cadherin 1 & 0.81 \\
\hline 41601 & Cdh1 & Cadherin 1 & 0.79 \\
\hline 28937 & Cdh3 & Cadherin 3 & 0.08 \\
\hline 13122 & Cdh10 & Cadherin 10 & 4.33 \\
\hline 16804 & Cdh11 & Cadherin 11 & 0.55 \\
\hline 14183 & Cdh13 & Cadherin 13 & 0.75 \\
\hline 36584 & Cdh17 & Cadherin 17 & 2.89 \\
\hline 9301 & Itga2 & Integrin $\alpha 2$ & 0.98 \\
\hline 7422 & Itga2b & Integrin $\alpha 2 b$ & 0.41 \\
\hline 11996 & Itga3 & Integrin $\alpha 3$ & 0.38 \\
\hline 28548 & Itga3 & Integrin $\alpha 3$ & 0.34 \\
\hline 40224 & Itga3 & Integrin $\alpha 3$ & 0.39 \\
\hline 32206 & Itga4 & Integrin $\alpha 4$ & 1.85 \\
\hline 16783 & Itga5 & Integrin $\alpha 5$ (fibronectin receptor $\alpha$ ) & 1.72 \\
\hline 5434 & Itga6 & Integrin $\alpha 6$ & 1.82 \\
\hline 9756 & Itga6 & Integrin $\alpha 6$ & 1.55 \\
\hline 28298 & Itga6 & Integrin $\alpha 6$ & 1.4 \\
\hline 1470 & Itga7 & Integrin $\alpha 7$ & 0.36 \\
\hline 20492 & Itga7 & Integrin $\alpha 7$ & 0.31 \\
\hline
\end{tabular}




\begin{tabular}{|c|c|c|c|}
\hline 36562 & Itgae & Integrin, $\alpha$ E, epithelial associated & 1.09 \\
\hline 1127 & Itgal & Integrin $\alpha \mathrm{L}$ & 1.25 \\
\hline 15941 & Itgav & Integrin $\alpha \mathrm{V}$ & 1.13 \\
\hline 30803 & Itgav & Integrin $\alpha \mathrm{V}$ & 1.18 \\
\hline 3878 & Itgb1 & Integrin $\beta 1$ (fibronectin receptor $\beta$ ) & 0.69 \\
\hline 5038 & Itgb1 & Integrin $\beta 1$ (fibronectin receptor $\beta$ ) & 0.8 \\
\hline 6517 & Itgb1 & Integrin $\beta 1$ (fibronectin receptor $\beta$ ) & 0.68 \\
\hline 7627 & Itgb1 & Integrin $\beta 1$ (fibronectin receptor $\beta$ ) & 0.71 \\
\hline 15484 & Itgb1 & Integrin $\beta 1$ (fibronectin receptor $\beta$ ) & 0.7 \\
\hline 15683 & Itgb1 & Integrin $\beta 1$ (fibronectin receptor $\beta$ ) & 0.69 \\
\hline 25292 & Itgb1 & Integrin $\beta 1$ (fibronectin receptor $\beta$ ) & 0.71 \\
\hline 26331 & Itgb1 & Integrin $\beta 1$ (fibronectin receptor $\beta$ ) & 0.72 \\
\hline 29211 & Itgb1 & Integrin $\beta 1$ (fibronectin receptor $\beta$ ) & 0.71 \\
\hline 33166 & Itgb1 & Integrin $\beta 1$ (fibronectin receptor $\beta$ ) & 0.69 \\
\hline 33758 & Itgb1 & Integrin $\beta 1$ (fibronectin receptor $\beta$ ) & 0.69 \\
\hline 17200 & Itgb1bp1 & Integrin $\beta$ 1-binding protein 1 & 0.73 \\
\hline 34448 & Itgb1bp1 & Integrin $\beta$ 1-binding protein 1 & 1.23 \\
\hline 33120 & Itgb2 & Integrin $\beta 2$ & 0.32 \\
\hline
\end{tabular}




\begin{tabular}{|c|c|c|c|}
\hline 5839 & Itgb3 & Integrin $\beta 3$ & 4.26 \\
\hline 35332 & Itgb3 & Integrin $\beta 3$ & 1.42 \\
\hline 6271 & Itgb3bp & Integrin $\beta$ 3-binding protein ( $\beta 3$-endonexin) & 2.12 \\
\hline 6449 & Itgb4 & Integrin $\beta 4$ & 0.23 \\
\hline 12964 & Itgb4 & Integrin $\beta 4$ & 0.23 \\
\hline 28162 & Itgb4 & Integrin $\beta 4$ & 1.23 \\
\hline 16065 & Itgb4bp & Integrin $\beta$ 4-binding protein & 0.8 \\
\hline 17137 & Itgb4bp & Integrin $\beta$ 4-binding protein & 0.9 \\
\hline 26110 & Itgb4bp & Integrin $\beta$ 4-binding protein & 0.8 \\
\hline 36438 & Itgb5 & Integrin $\beta 5$ & 2.61 \\
\hline 8658 & Itgb6 & Integrin $\beta 6$ & 1.07 \\
\hline 22943 & Itgb6 & Integrin $\beta 6$ & 1.55 \\
\hline 39766 & Itgb6 & Integrin $\beta 6$ & 1.64 \\
\hline 12531 & Itgb7 & Integrin $\beta 7$ & 0.35 \\
\hline 42875 & Crb3 & Crumbs homolog 3 (Drosophila) & 0.16 \\
\hline 33819 & Crb1 & Crumbs homolog 1 (Drosophila) & 1.37 \\
\hline 24656 & Jam4 & Junctional adhesion molecule 4 & 0.99 \\
\hline 28942 & Jam2 & Junctional adhesion molecule 2 & 19.84 \\
\hline
\end{tabular}




\begin{tabular}{|c|c|c|c|}
\hline 40749 & Jam4 & Junctional adhesion molecule 4 & 0.97 \\
\hline 32468 & L1cam & L1 cell adhesion molecule & 0.17 \\
\hline 38348 & Vezt & $\begin{array}{l}\text { Vezatin, adherens junctions transmembrane } \\
\text { protein }\end{array}$ & 0.86 \\
\hline 10279 & Cdc42 & $\begin{array}{l}\text { Cell division cycle } 42 \text { homolog } \\
\text { (Saccharomyces cerevisiae) }\end{array}$ & 1.07 \\
\hline 15744 & Cdc42 & $\begin{array}{l}\text { Cell division cycle } 42 \text { homolog } \\
(\text { S cerevisiae) }\end{array}$ & 0.79 \\
\hline 33085 & Cdc42 & $\begin{array}{l}\text { Cell division cycle } 42 \text { homolog } \\
\text { (S cerevisiae) }\end{array}$ & 1.12 \\
\hline 6306 & Cgn & Cingulin & 0.91 \\
\hline 22246 & Cgn & Cingulin & 0.64 \\
\hline 34374 & Cgn & Cingulin & 0.64 \\
\hline 32668 & Dlg7 & Discs, large homolog 7 (Drosophila) & 0.66 \\
\hline 33705 & Dlg7 & Discs, large homolog 7 (Drosophila) & 0.56 \\
\hline 35046 & Dlg5 & Discs, large homolog 5 (Drosophila) & 0.66 \\
\hline 35772 & Dlgh1 & Discs, large homolog 1 (Drosophila) & 0.56 \\
\hline 36439 & Dlgh3 & Discs, large homolog 3 (Drosophila) & 0.34 \\
\hline 770 & Dlgh1 & Discs, large homolog 1 (Drosophila) & 0.43 \\
\hline 7348 & Dlg5 & Discs, large homolog 5 (Drosophila) & 0.58 \\
\hline 34455 & Rab13 & RAB13, member RAS oncogene family & 0.58 \\
\hline
\end{tabular}




\begin{tabular}{|c|c|c|c|}
\hline 17836 & Dsp & Desmoplakin & 0.83 \\
\hline 23455 & Dsp & Desmoplakin & 0.82 \\
\hline 36611 & Dsp & Desmoplakin & 0.87 \\
\hline 21804 & $\mathrm{Vcl}$ & Vinculin & 0.41 \\
\hline 25846 & $\mathrm{Vcl}$ & Vinculin & 0.56 \\
\hline 5744 & Tln1 & Talin 1 & 0.85 \\
\hline 10197 & Tln1 & Talin 1 & 0.74 \\
\hline 12934 & Tln2 & Talin 2 & 0.44 \\
\hline 14973 & Tln2 & Talin 2 & 0.47 \\
\hline 27311 & Tln1 & Talin 1 & 0.94 \\
\hline 40914 & Ilk & Integrin-linked kinase & 0.7 \\
\hline 15769 & Flna & Filamin, $\alpha$ & 0.42 \\
\hline 25062 & Flna & Filamin, $\alpha$ & 0.62 \\
\hline 38232 & Flna & Filamin, $\alpha$ & 0.37 \\
\hline 406 & Flnb & Filamin, $\beta$ & 0.68 \\
\hline 2498 & Flnb & Filamin, $\beta$ & 0.53 \\
\hline 11971 & Flnb & Filamin, $\beta$ & 0.57 \\
\hline 13550 & Flnb & Filamin, $\beta$ & 0.59 \\
\hline 40558 & Flnb & Filamin, $\beta$ & 0.6 \\
\hline
\end{tabular}




\begin{tabular}{|l|l|l|l|} 
& Flnc & Filamin c, $\gamma$ (actin-binding protein 280) & 2.12 \\
\hline 27334 & Flnc & Filamin c, $\gamma$ (actin-binding protein 280) & 2.07 \\
\hline 30827 & Flnc & Filamin c, $\gamma$ (actin-binding protein 280) & 2.32 \\
\hline & & & \\
\hline
\end{tabular}

NOTE. Agilent Technologies (Santa Clara, CA) equipment was used for oligonucleotide microarray analysis. 